Canadian Journal of Higher Education

Revue canadienne d'enseignement supérieur

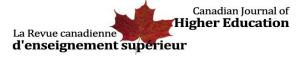

\title{
The Role of Library Councils in Canadian Higher Education: An Exploratory Study
}

\section{Eva Revitt and Sean Luyk}

Volume 49, Number 1, 2019

URI: https://id.erudit.org/iderudit/1060828ar

DOI: https://doi.org/10.7202/1060828ar

\section{See table of contents}

Publisher(s)

Canadian Society for the Study of Higher Education

ISSN

2293-6602 (digital)

Explore this journal

Cite this article

Revitt, E. \& Luyk, S. (2019). The Role of Library Councils in Canadian Higher Education: An Exploratory Study. Canadian Journal of Higher Education / Revue canadienne d'enseignement supérieur, 49(1), 140-158.

https://doi.org/10.7202/1060828ar
Article abstract

Scholarship exploring the makeup, function, and efficacy of collegial governance structures within the context of Canadian higher education is limited and primarily focused on the board or the senate. This paper expands that scholarship by focusing on the governance structures of the university library. The objective of this study was to determine the extent of library councils in Canadian universities and to examine their composition, role, and function as evidenced in their governing documents. Using Karl Mannheim's document method to analyze the terms of reference of 23 library councils, findings reveal that, overwhelmingly, library councils function as information-sharing and discussion forums rather than decision-making bodies. The paper concludes with a review of progressive language and governance practice as gathered from the document analysis.
This document is protected by copyright law. Use of the services of Érudit (including reproduction) is subject to its terms and conditions, which can be viewed online.

https://apropos.erudit.org/en/users/policy-on-use/ 
Canadian Journal of Higher Education Revue canadienne d'enseignement supérieur

Volume 49, No. 1, 2019, pages $140-158$

\title{
The Role of Library Councils in Canadian Higher Education: An Exploratory Study
}

Eva Revitt

MacEwan University

Sean Luyk

University of Alberta

\begin{abstract}
Scholarship exploring the makeup, function, and efficacy of collegial governance structures within the context of Canadian higher education is limited and primarily focused on the board or the senate. This paper expands that scholarship by focusing on the governance structures of the university library. The objective of this study was to determine the extent of library councils in Canadian universities and to examine their composition, role, and function as evidenced in their governing documents. Using Karl Mannheim's document method to analyze the terms of reference of 23 library councils, findings reveal that, overwhelmingly, library councils function as information-sharing and discussion forums rather than decision-making bodies. The paper concludes with a review of progressive language and governance practice as gathered from the document analysis.
\end{abstract}

\section{Résumé}

La recherche sur la composition, les fonctions, et l'efficacité des structures de gouvernance collégiale dans le contexte des universités canadiennes est limitée et se concentre surtout sur le conseil des gouverneurs et le sénat. Cet article élargit la recherche en se focalisant sur les structures de gouvernance de la bibliothèque universitaire. L'objectif de cette étude est d'établir l'étendue des conseils de bibliothèques dans les universités canadiennes et d'examiner 
leur composition, leur rôle, et leur fonction interne tels que démontrés dans leurs documents constitutifs. En analysant les mandats de 23 conseils de bibliothèque selon la méthode documentaire de Karl Mannheim, il en résulte très clairement que les conseils de bibliothèque fonctionnent plutôt comme forum d'échange d'information et de discussion qu'en tant qu'organisme décisionnel. D'après l>analyse documentaire, l'article se termine par un examen du langage visionnaire et de la pratique en matière de gouvernance.

\section{Introduction}

Library councils, also variously named as librarians' councils, library faculty councils, or library and archives councils, are collegial bodies that parallel faculty or school councils (Canadian Association of College and University Librarians/Canadian Association of College and University Teachers [CACUL/CAUT], 1979; Revitt \& Luyk, 2016). Their role and purpose was set out in 1977 when the CACUL and the CAUT jointly released their Guidelines on Academic Status for University Librarians. Among other things, the Guidelines stressed librarians' participation in university and library governance:

The university library system should operate under internal policies and procedures which are analogous to those used in the traditional academic Faculties. While the Chief Librarian, analogous to the Dean of an academic Faculty, should have overall responsibility for the operation of the library system, the policies and procedures of the system as a whole should be determined by a Library Council which is responsible to the Senate and which is composed of full-time professional librarians as voting members, as well as representatives from elsewhere in the University. (CACUL/CAUT, 1979, p. 1)

The authors were curious about the existence of present-day library councils in Canadian universities and wanted to determine if their composition and function within the library and the broader university aligned with the Guidelines.

The role and purpose of library councils and the governance of the academic library should be of concern within the academy and beyond. Scholarship by Lipinski (1999), Trosow (2014), and Lariviere, Haustein, and Mongeon (2016) demonstrates disturbing corporate reach and ambitions to commodify information and the public domain. In the post-truth era of alternative facts and assault on all things public, including public spaces (Giroux, 2001), libraries (including those found in academic institutions) are sites of resistance. They are intellectual, communal, and thoroughly interdisciplinary spaces wellpositioned to push back against anti-intellectualism and to facilitate collaboration across disciplines, skillsets, abilities, knowledge domains, and groups. Librarians, as library and information studies experts, have the technological and disciplinary expertise to support, develop, and lead such collaborations, and to foster critical engagement with information and information environments. As the nexus where disciplines converge, the library's policies, initiatives, and strategic direction cut across all faculties and should be vetted through deliberative processes. As one of the most highly used spaces on campus, ${ }^{1}$ the academic library is an important contributor to students' learning experience and a valuable communal space. Its governance should not be overlooked. 
Academic libraries are also cost centres. The national average for academic library expenditures as a percentage of university expenditures is $4.38 \%$ (Canadian Association of Research Libraries [CARL], 2017); and although there is some evidence that university library budgets are declining (Shaker \& Shaban, 2017), they are well in the millions of dollars, with that of the University of Toronto nearing 100 million (CARL, 2017). Such investments demand accountability, and libraries have not been immune to the market orientation and challenges faced by today's universities. A preoccupation with assessment, streamlined services, endless innovation, and demonstrating the value of the academic library dominate professional and scholarly discourse (Jantz, 2017; Matthews, 2015; Nelson \& Fernekes, 2002; Nicholson, 2015; Oakleaf, 2010).

For instructional faculty, issues of academic relevance can be debated and decided in legislated forums such as a faculty or school council. Faculty councils are ubiquitous bodies at Canadian universities that deliberate, review, and approve academic policy within the scope of their respective disciplines such as medicine, law, or education. Almost all faculty councils derive their authority from either the senate, the university board, or provincial legislation (Pennock, Jones, Leclerc, \& Li, 2016); this authority includes the following:

making rules for the government, direction, and management of the faculty and its affairs and business; appointing examiners for examinations in the faculty; determining courses of instruction; and prohibiting the teaching in the faculty by other than properly appointed members of the teaching staff. (Davis, 2015, pp. 70-71)

While the source of authority for faculty councils varies across Canadian universities, it nevertheless bestows a level of credibility to the council as a deliberative and authoritative body and underscores the council's permanence within the overall institutional governance framework and its role in academic governance.

Despite limited scholarship exploring collegial governance within Canadian university libraries, there is evidence that library councils, where they exist, function primarily as discussion and information-sharing forums rather than governance bodies with decision-making authority (Jacobs, 2008; Revitt \& Luyk, 2016), and that librarians are marginalized and disenfranchised from significant decisions affecting library operations, policy development, and the appointment and evaluation of senior library administrators (Granfield, Kandiuk, \& Sonne de Torrens, 2011; Petter, 2012; Ribaric, 2014; Savage, 1982; Sonne de Torrens, 2014; Turk, 2010). Joan Wallach Scott (2002), a one-time chair of the American Association of University Professors' Committee on Academic Freedom and Tenure, makes the point that "faculty's role in governance....is the foundation for academic freedom" (p. 42). Depriving academic librarians of collegial governance processes not only undermines their rights to academic freedom, but also affects the development of library services, resources, and policies. Built into the professional ethos of librarianship is the belief that the freedom to access information is a human right, and its distribution is a matter of social justice and the public good. ${ }^{2}$ It is important that professional ethics and values of librarianship are part of the discourse in the development and evolution of the academic library and its resources and services.

Scholarship exploring the makeup, function, and efficacy of collegial governance structures within the context of Canadian higher education is limited, and primarily focused on higher education boards and governance of finances (Chan \& Richardson, 2012; Lang, 
2016; Trotter, 2009), with a few studies focused on the senate (Jones, Shanahan, \& Goyan, 2004; Lougheed \& Pidgeon, 2016; Pennock et al., 2016). A conference entitled "Academic Governance 3.0," organized in 2012 by the University Faculty Association of British Columbia, as well as a 2016 special issue on higher education governance in the Canadian Journal of Higher Education (Volume 46, no. 3), have done much to advance the scholarly conversation regarding collegial governance in the post-secondary sector. This paper expands that conversation through its focus on the governance structure of the university library. Library and information studies scholarship that explores academic library governance is minimal, dated, and mostly limited to the U.S. context (Ackerman, 1980; Brown, 1985; Lowry, 1974; Lesniaski, MacPherson, Fister, \& McKinzie, 2001; Merikangas, 1999), with a few published and unpublished works centred on the state and evolution of library councils and self-governance processes in Canadian university libraries (Jacobs, 2008; Ribaric, 2014; Ryan, 2015; Revitt \& Luyk, 2016). Within the scholarly discourse of higher education literature, library governance is completely absent. This paper fills an important gap by highlighting the issue of library governance and its relevance to higher education.

\section{Historical Context}

Librarians working in Canadian universities today are predominantly academic staff with rights and responsibilities articulated and protected alongside those of faculty in collective agreements (CAUT, 2018). This has not always been the case. Librarianship is a female-intensive profession with a marked history of sexism, spirited debates, and courageous action by librarians who challenged the status quo to achieve bargaining rights (Savage, 1982; Dekker \& Kandiuk, 2014). By the 1970s, the CAUT (1976) recognized that "although librarians were in a different category from other faculty members, as academic colleagues, they were entitled to corresponding protection" (p. 19). In 1977, CACUL and CAUT jointly released the Guidelines on Academic Status for University Librarians (CACUL/CAUT, 1979). The Guidelines set out procedures and criteria for appointment, stressed progression through the ranks, articulated procedures for dismissal and grievances, and supported librarians' eligibility for sabbatical leave and participation in university and library governance. In an examination of the CAUT Bulletin from its inception in 1953 to the present, Revitt and Luyk (2016) traced the discourse around library councils and concluded that the development of collegial governance structures, once considered an inevitable outgrowth of librarians' academic status, was marked by "'fits and starts,' sexism, and administrative hesitance" (p. 62). Yet democratic principles and deliberative processes as a basis for decision making are not new to librarianship (Danton, 1934; Ellis, 1980; Ranganathan, 1931).

As early as 1931, S.R. Ranganathan, author of one of the profession's foundational works, The Five Laws of Library Science, proposed that libraries with a large staff component would benefit from a staff council. Such a council, he argued, would foster a collective sense of responsibility and ownership (pp. 410-411). Almost at the same time, J. Periam Danton, former dean of the School of Librarianship, University of California, questioned the efficacy of the academic library's hierarchical model and argued that every staff member should have "a controlling voice in the administration of the institution in which he works" (Danton, 1934, p. 18). Closer to home, Richard Ellis, Head of Collections and Acquisitions and then University Librarian of Memorial University Libraries, argued for the 
creation of a library council comprised of all librarians that would consider "all policy matters relating to the library, both academic and non-academic" (Ellis, 1980, p. 10).

This aspiring rhetoric appears to have had minimal impact on the development of democratic decision processes within the academic library. How librarians value and conceptualize collegiality may provide some insight into why this is so. In a survey conducted for the Massachusetts State Colleges Association, 85\% of the respondents defined collegiality as "treating each other with respect, fairly," while the second most common response was "working together effectively among individuals holding the same rank or power"' (Freedman, 2012, p. 110). Libraries are collaborative institutions-internally and externally-and the work of librarians often requires teamwork and collaboration with other libraries and campus departments. For example, libraries were some of the earliest adopters of computer technology and have been collaboratively sharing bibliographic data since the 1960s (Fons, 2016). Librarians' work is inherently collaborative and increasingly so as ubiquitous technologies foster "edgeless environments" (Davies, 2013), the convergence of public-facing services, and the development of collaborative networks and community partnerships (Weaver, 2013). Among academic librarians, collegial and collaborative relationships are a necessary cultural norm. Collegiality, however, is not congeniality (CAUT, 2005), and professional norms may be a contributing factor in the slow development and establishment of deliberative processes within academic librarianship. As stressed by Freedman (2012), collegiality is about cooperative interactions, shared power, and shared authority among colleagues. However, within librarianship, the focus tends to be on interpersonal relationships rather than interprofessional work and a common purpose (Freedman, 2012). In a blog post entitled "Academic Freedom, Tenure \& Collegiality for Librarians," Giustini (2007) makes the point that within librarianship collegiality has become synonymous with being agreeable:

A collegial person doesn't rock the boat, goes with the flow, supports prevailing sentiments, and doesn't make waves. Such a person may advocate for an idea, but doesn't push if others are uncomfortable with it. A collegial librarian preserves the comfort level of colleagues. (para. 3)

Giustini cautions that such an acceptance of collegiality is dangerous: "The ideal of 'being agreeable' is problematic when outspokenness would be better" (para. 4). Edwards (2003) makes the point that if the goal is getting along, the end result may be preordained.

Given the negligible presence of collegial governance structures in academic libraries and the very sparse scholarship on the topic, librarians working at Dickinson College, in Pennsylvania, and St. Olaf and Gustavus Adolphus colleges, both in Minnesota, offer a unique example of such a structure. While the practice and definition of collegial governance evolved over time at these institutions and is subject to local contexts, the authors stress three principles that are foundational to the colleges: shared leadership responsibilities and decision making (the position of the college librarian rotates among librarians), a non-hierarchical management structure and fluid reporting lines, and an emphasis on process and communication rather than authority (Lesniaski et al., 2001).

Lesniaski et al. (2001) describe St. Olaf as a college with three libraries and 24 librarians and staff, and make the point that while a hierarchical structure may seem reasonable in an organization of that size and complexity, it never took root at St. Olaf. A collegial 
governance model developed because of the library's modest beginnings and its consultative director. The collegial governance experience of librarians at Dickinson, St. Olaf, and Gustavus Adolphus colleges challenges the argument that collegial governance is incompatible with the nature of librarians' work and the inherently hierarchical structure of the academic library (Beckman, 1976; Eadie, 1978). It also suggests that institutional culture and administrative prerogative are considerable factors in its implementation and success. There is no documentation to suggest that any academic library in Canada demonstrates an equivalent level of collegial governance and decision-making to that described at Dickinson, St. Olaf, and Gustavus Adolphus colleges. The lack of published information on collegial governance in academic libraries in Canada underscores the importance of this exploratory study.

A decade ago, Jacobs (2008) posted an informal request on the CAUTLIB and CACUL- $\mathrm{L}^{3}$ listservs to determine the extent and composition of library councils in Canada and to gain insight regarding their function. Jacobs received responses from 28 librarians representing 25 academic libraries, 13 of which had something "approximating" a library council. Only three respondents considered their council effective "because [it] provided a forum for communication and discussion" (p. 14). None considered the council to be a deliberative, decision-making body. Building on Jacob's work, and with the goal of more systematically assessing the extent, composition, and function of library councils in Canadian universities, the authors conducted a document analysis of the terms of reference, also referred to as bylaws or constitutions, of 23 library councils.

\section{Method}

Documents can serve to represent the underlying social realities of the contexts in which they were created, and are essential for studying organizations in literate societies (Atkinson \& Coffey, 1997). In researching library councils, it was determined that obtaining the official documents that concretized their existence would be an asset in determining the councils' authoritative scope, composition, and purpose. Document analysis offered a way of testing the authors' understanding of library councils in Canadian universities as drawn from the limited literature on the subject (Revitt \& Luyk, 2016) against evidence found in actual terms of reference for library councils.

As a research method, document analysis is an unobtrusive qualitative method useful as a means of triangulation with other sources of qualitative data (Bowen, 2009). The approach to document analysis used in this study was drawn from the influential sociologist Karl Mannheim's documentary method, where "the text is used to furnish indications or traces of what the reader interprets as the 'underlying' social reality" (Atkinson \& Coffey, 1997, p. 85). Mannheim's method was chosen because of its longstanding influence as a foundational method of interpretation in the social sciences (Bohnsack, 2014). Proceeding from Atkinson and Coffey's (1997) understanding of documents as "social facts," the following commonly accepted method of document analysis was applied: finding, selecting, appraising, synthesizing, and organizing (Bowen, 2009). Throughout the data analysis process, the finding and selecting stages were distinct; however, the appraising, synthesizing, and organizing stages occurred simultaneously and involved judgement and careful assessment. Thus, the section below outlining appraising encompasses the latter three stages together. 


\section{Finding}

In January 2016, 82 heads of university libraries were contacted via email with a request to share their library council or equivalent governance documents. The name and contact information for the heads of libraries was gathered from library websites and compiled by a research assistant. The 82 libraries were selected from the list of 96 member institutions of Universities Canada. Fifteen libraries were excluded, including those at primarily religious institutions, constituent colleges of larger institutions, research institutions without a teaching component, and institutions that were not universities but maintained membership in Universities Canada. The authors' institutions were also excluded from the email as the library council governance documents were readily available. The exclusion criteria were put in place to ensure the governance documents of library councils were from like institutions-academic libraries within universities.

The email text to the head of the library, often referred to as the university librarian, chief librarian, or dean of libraries, explained the purpose of the research: (1) to determine the prevalence of library councils in Canadian university libraries; (2) to determine the membership, procedures, purpose, and scope of such bodies; and (3) to create a publicly available online repository of the terms of reference (constitutions or bylaws) of the councils in order to promote a better understanding of collegial governance structures in Canadian university libraries.

Respondents were invited to share their governing documents or else confirm on a clickable survey form that their library did not have a library council or similar body. Twenty-eight email responses from the heads of libraries were received, all of which indicated that their institution had a library council or similar body, although not all provided documents, and 14 survey responses confirmed that the library did not have a library council or similar body. No responses were received from 40 heads of libraries-a likely indication that library councils and governance processes within academic libraries remain poorly understood. The 28 individuals who did respond to the email either provided the requested documents or indicated where the relevant data can be found, such as in a clause in a collective agreement. A few included explanatory notes about the history and current status of their library council and other factors related to library governance at their institution.

Direct email contact was essential to gathering the data as the overwhelming majority of library governance documents are not publicly available on library or institutional websites. At the time of the study, the exceptions were Dalhousie University Libraries and Mount Royal University Library, which posted their Library Council Terms of Reference (Dalhousie) and Library Faculty Council Committee Charter (Mount Royal) on their respective websites.

Dalhousie Libraries' inclusion of Council agendas and minutes is doubly commendable and reflects a unique level of transparency and commitment to process. The hesitancy, or perhaps indifference, to post documentation related to library governance for publicly mandated and funded institutions is disconcerting and points to a general disregard for and unease with the concept, structure, and process of collegial governance within Canadian university libraries.

In addition to the documents that were shared, an extensive document reconnaissance was conducted, focusing specifically on the 40 libraries from which no response was re- 
ceived. Library websites were examined for any indication of governance structures, such as the presence of a council or like body in an organizational chart. A search was conducted for "library councils" and related language in the CAUT's database of collective agreements, and efforts were made to reach out to colleagues at various institutions to ascertain the presence of such a body. In some instances, trace evidence, online or anecdotal, pointed to the existence of a library council but efforts to locate or obtain the necessary documents were unsuccessful. The findings were crosschecked against Jacobs (2008) to ensure that the institutions listed in that write-up were included in this study. Two institutions that Jacobs lists but for which the authors were unable to locate or obtain documents are the University of Calgary Libraries and the University of Winnipeg Library.

\section{Selecting}

In selecting the documents for this study, three criteria were applied to distinguish library councils from related bodies such as library advisory committees or management committees. For a university library and its library governance documentation to be included in this analysis, it had to meet these three criteria: (1) its existence concretized in a term of reference or like document, (2) a membership that consists of the majority of librarians employed at the institution, and (3) evidence that the council is active, such as an indication of the frequency of meetings. A few libraries appeared to have an informal library council or like body that meets regularly or infrequently but whose existence, mandate, and process was not otherwise documented. Although these councils or like bodies are functioning, their very informal nature made it impossible to distinguish them from a typical staff meeting. These informal bodies did not meet the threshold of a library governance structure and were excluded from the study.

All documentation received or gathered was examined independently by the researchers against each of the three criteria and marked on individual spreadsheets. The spreadsheets were then cross-referenced. To resolve cases of disagreement regarding whether or not specific criteria were met, the researchers re-examined the documentation and corresponding email responses to arrive at a consensus. The documents varied in both size and complexity, with the shortest being a paragraph and the longest stretching to six pages in length. The application of the three criteria resulted in the selection of 23 documents representing library councils or like bodies.

\section{Appraising, Synthesizing, and Organizing}

Library council governance documents were appraised, combined, and organized based on the following factors: scope and purpose, rules of procedure, and connection to institutional governance bodies.

Scope and purpose. The scope and purpose of the 23 library council governance documents analyzed did not vary to a great extent, and revealed that the majority of councils serve primarily in an advisory capacity-most often to the university librarian or title equivalent-and few operate as collegial decision-making bodies with any discernible power. The advisory character of library councils is often stressed in the initial paragraph and typically precedes all other information; for example: "The Library Council is responsible for making recommendations to the Chief Librarian," or "The role of the Library Council is 
to (1) Provide the University Librarian with library wide perspectives," or "The Council is advisory to the University Librarian or equivalent." Conciliatory phrases such as "to consider matters," "pitch ideas for innovation," and "official means of consultation between the university librarian and the librarians" further underscored the power imbalance between the library's most senior administrator and the council body. The councils are also typically described as information-sharing and deliberative bodies, as evident in terms such as "venue for discussion and information sharing," "forum for discussion," and "Council's deliberations should avoid matters of detail and management of individual units."

Some library councils have a mandate to fulfill their duties as outlined in the collective agreement, most often regarding peer review. For example, the Brock Library Council terms of reference show that the Council is responsible for making recommendations for appointments and promotions and establishing criteria for annual reviews. Similarly, one of the purposes of the University of Alberta Library Council is to "perform those duties required of it by the Librarians' Agreement," which includes oversight over a Library Evaluation Committee, Position Review Committee, and the General Appeals Committee.

Rules of procedure. There was simply was not enough detail in the majority of the documents to reveal clear rules of procedure, perhaps further underlining the tendency for the councils to operate in general advisory and information-sharing capacities. Although 20 of the 23 documents contained references to some key procedural pieces, such as membership, quorum, and the frequency of meetings, few delved deeper into areas that get at the heart of decision-making. For example, only four of the 23 documents analyzed made reference to formal rules of procedure (e.g., Robert's Rules of Order, Bourinot's Rules of Order). Similarly, voting and the making of motions were only described in detail in three of the documents analyzed (Dalhousie, Kwantlen, and Memorial). Three of the council documents did not contain any information about procedure.

Connection to institutional governance bodies. The terms of reference were also examined for evidence of the councils being connected to the broader institutional governance framework through the senate or equivalent body. An example of language indicative of a wider accountability mandate is found in the documents of the Mount Allison University Library Council: "[to] make recommendation to the appropriate bodies and officials of the Employer"; the Laurentian Library and Archives Council which "shall make recommendations to the Senate"; and the Memorial University Library Academic Council: "The function of the Academic Council shall be to make recommendations to the University Senate.” Although a number of institutions include language in the collective agreement for a library council, few provided accountability details sufficient to help ensure the council functions as a collegial decision-making body. For example, the library council clause in the University of Alberta Librarian Agreement simply states what the library council composition is, not what work it performs, or where its accountability lies:

a council, chaired by the Chief Librarian, which includes all staff members employed in the University of Alberta Library System, and such other member of the academic staff employed in the University Libraries. For the purposes of this Agreement, voting on decisions required by this Agreement shall be restricted to the staff members. 


\section{Results and Discussion}

Of the documents examined, 11 were clauses or articles from collective agreements, and 14 were stand-alone terms of reference not connected to either the senate or a collective agreement. For some library councils, such as that at the University of Alberta, there exists both a terms of reference document and a clause in the collective agreement. In other library council documents, such as that of Brock University Library, there is a procedures document outlining rules and logistics that appears to complement language in the library council clause in the collective agreement. Most significantly, of the 23 documents examined, the terms of reference for only five library councils provide a formal link to the university senate. None of the 23 derive their authority from the university board or a legislative statute. The placement of the library council within the parent institution is potentially a significant determining factor regarding the council's level of authority and institutional credibility. Library councils that report to the senate or equivalent likely have more impact. The lack of institutional recognition of library councils as an authoritative body for the overwhelming majority indicates that their ability to influence decisionmaking is limited. The findings are listed in Table 1.

Table 1. Library Councils and their Institutional Connections

\begin{tabular}{|c|c|c|c|c|c|}
\hline & University & Council Name & $\begin{array}{l}\text { Council is } \\
\text { Stand-Alone }\end{array}$ & $\begin{array}{l}\text { Council is Refer- } \\
\text { enced in the Col- } \\
\text { lective Agreement }\end{array}$ & $\begin{array}{l}\text { Council is } \\
\text { Connected to } \\
\text { the Senate }\end{array}$ \\
\hline 1 & $\begin{array}{l}\text { Atlantic School } \\
\text { of Theology }\end{array}$ & Library Council & & $\mathrm{x}$ & \\
\hline 2 & Brock University & Library Council & & $\mathrm{x}$ & \\
\hline 3 & $\begin{array}{l}\text { Dalhousie } \\
\text { University }\end{array}$ & Library Council & $\mathrm{x}$ & & \\
\hline 4 & $\begin{array}{l}\text { Kwantlen } \\
\text { Polytechnic } \\
\text { University }\end{array}$ & $\begin{array}{l}\text { Regular Library } \\
\text { Faculty } \\
\text { Meetings }\end{array}$ & $\mathrm{x}$ & & \\
\hline 5 & $\begin{array}{l}\text { Laurentian } \\
\text { University }\end{array}$ & $\begin{array}{l}\text { Library and } \\
\text { Archives Council }\end{array}$ & & $\mathrm{x}$ & $\mathrm{x}$ \\
\hline 6 & $\begin{array}{l}\text { MacEwan } \\
\text { University }\end{array}$ & $\begin{array}{l}\text { Library Faculty } \\
\text { Council }\end{array}$ & $\mathrm{x}$ & & \\
\hline 7 & $\begin{array}{l}\text { Memorial } \\
\text { University }\end{array}$ & Academic Council & $\mathrm{x}$ & & $\mathrm{x}$ \\
\hline 8 & $\begin{array}{l}\text { Mount Allison } \\
\text { University }\end{array}$ & Library Council & & $\mathrm{x}$ & $\mathrm{x}$ \\
\hline 9 & $\begin{array}{l}\text { Mount Royal } \\
\text { University }\end{array}$ & $\begin{array}{l}\text { Library Faculty } \\
\text { Council }\end{array}$ & $\mathrm{x}$ & & $\mathrm{x}$ \\
\hline 10 & $\begin{array}{l}\text { Ryerson } \\
\text { University }\end{array}$ & Library Council & $\mathrm{x}$ & & \\
\hline
\end{tabular}




\begin{tabular}{|c|c|c|c|c|c|}
\hline & University & Council Name & $\begin{array}{l}\text { Council is } \\
\text { Stand-Alone }\end{array}$ & $\begin{array}{l}\text { Council is Refer- } \\
\text { enced in the Col- } \\
\text { lective Agreement }\end{array}$ & $\begin{array}{l}\text { Council is } \\
\text { Connected to } \\
\text { the Senate }\end{array}$ \\
\hline 11 & $\begin{array}{l}\text { Saint Mary’s } \\
\text { University }\end{array}$ & Library Council & & $\mathrm{x}$ & \\
\hline 12 & $\begin{array}{l}\text { Simon Fraser } \\
\text { University }\end{array}$ & Library Council & $\mathrm{x}$ & & \\
\hline 13 & Trent University & $\begin{array}{l}\text { Librarians' } \\
\text { Committee }\end{array}$ & & $\mathrm{x}$ & \\
\hline 14 & $\begin{array}{l}\text { University of } \\
\text { Alberta }\end{array}$ & Library Council & $\mathrm{x}$ & $\mathrm{x}$ & \\
\hline 15 & $\begin{array}{l}\text { University of } \\
\text { Lethbridge }\end{array}$ & $\begin{array}{l}\text { Library Advisory and } \\
\text { Planning Committee }\end{array}$ & $\mathrm{x}$ & & \\
\hline 16 & $\begin{array}{l}\text { University of } \\
\text { Manitoba }\end{array}$ & Librarians' Council & $\mathrm{x}$ & & \\
\hline 17 & $\begin{array}{l}\text { University of } \\
\text { New Brunswick }\end{array}$ & Library Board & $\mathrm{x}$ & & \\
\hline 18 & $\begin{array}{l}\text { University of } \\
\text { Ottawa }\end{array}$ & Library Council & & $\mathrm{x}$ & \\
\hline 19 & $\begin{array}{l}\text { University of } \\
\text { Prince Edward } \\
\text { Island }\end{array}$ & Library Council & & $\mathrm{x}$ & \\
\hline 20 & $\begin{array}{l}\text { University of } \\
\text { Regina }\end{array}$ & $\begin{array}{l}\text { Librarians' and } \\
\text { Archivists' Council }\end{array}$ & $\mathrm{x}$ & & \\
\hline 21 & $\begin{array}{l}\text { University of } \\
\text { Victoria }\end{array}$ & Libraries Council & $\mathrm{x}$ & & \\
\hline 22 & $\begin{array}{l}\text { University of } \\
\text { Windsor }\end{array}$ & $\begin{array}{l}\text { University Library } \\
\text { Administrative } \\
\text { Committee }\end{array}$ & & $\mathrm{x}$ & \\
\hline \multirow[t]{2}{*}{23} & $\begin{array}{l}\text { Wilfrid Laurier } \\
\text { University }\end{array}$ & Library Council & $\mathrm{x}$ & $\mathrm{x}$ & $\mathrm{x}$ \\
\hline & & TOTAL & 14 & 11 & 5 \\
\hline
\end{tabular}

The phrase "academic matters" or "academic affairs" finds its way to almost half of the examined documents; however, none of the documents examined define it. It is suspected that the phrase is undefined because the matter of what constitutes "academic matters" within the context of the university library is not at all clear. Conceived in the strictest sense, academic matters could be limited to librarians' teaching activities and/or evaluation and promotion processes. The phrase is thus problematic. Librarians' participation in evaluation and promotion processes is an important governance role, but it should not be the only purpose of a council.

The indeterminacy of academic matters underscores the persistent confusion regarding the role and purpose of library councils (Jacobs, 2008). For example, some university librarians indicated that their library did not have a library council or similar body, yet 
the documents they shared demonstrated they did. In other cases, respondents indicated that they did have a library council or like body, yet the documents revealed that, by any standard definition of a collegial governance body, they did not. Specifically, respondents conflated the concept of a library advisory committee with the concept of a library council. Library advisory committees are typically comprised of members external to the librarynamely, students and faculty-with few key members from the library. Library advisory committees provide feedback and advice regarding library services, resources, initiatives, and policy development, and as such they play an important consultative role in ensuring that the library is meeting the academic needs of its constituent groups. However, unlike a library council, the library advisory committee is not a body where the professional and disciplinary expertise for library and information science resides, and where decisionmaking regarding library policy and strategic direction takes place. While some library councils do include student, faculty, or other representatives in their membership, the majority must always be professional librarians.

Despite the library councils' overall underdeveloped status, language that is more aligned with collegial governance principles of shared welfare for the organization, mutual trust and respect, and an active and engaged membership was also encountered. These included: "The Library Council...is the deliberative body responsible for academic affairs of the Library and expresses its collective will [emphasis added]" (Mount Royal University); "The objectives of the Council shall be...to actively participate in the development of library policies and procedures, long-term planning, and future directions of library services" (Mount Allison University); "Recommendations of the Library Council shall be considered by the University Librarian" (Saint Mary's University); and "It provides a formal structure for faculty members in the Library to exercise self-governance in academic matters" (MacEwan University).

Other progressive language and governance practices as collectively gained from this study include, for example, a consent agenda (MacEwan University Library Faculty Council). A consent agenda groups routine items, such as committee reports and updates from the university librarian and other senior administrators that are reported on at every meeting, and includes these in the agenda package. These are usually non-controversial items that can be approved with a single motion. Consent agendas can be an efficient time management tool for council meetings. Kwantlen University Library faculty meetings include an agenda with prepared motions, which aids in creating transparent systems of decision making. In five of the documents examined, the university librarian occupies the role of colleague and not chair, which aligns with more egalitarian systems of decisionmaking. Such an arrangement promotes open dialogue, as the most senior administrator is not preoccupied with matters of procedure and can fully engage in the discussion at hand. This arrangement further dispels notions of "conflict of interest" (Jacobs, 2008, p. 10) and administrative control. The position of council chair is elected or rotated and has a specified term limit. Meetings are scheduled for the upcoming year. The agenda is distributed at least one week in advance of the meeting. The council meeting follows established rules of order. Minutes are distributed to all members for approval and correction. Minutes, agendas, and council's terms of reference are publicly posted. Council is open to library staff and MLIS co-op students as observers. The focus is on broader policy issues rather than operational matters: the why versus the how. For example, the terms 
of reference for Ryerson University Library Council state: "Deliberations should normally avoid matters of detail and management of individual units, unless they have broader significance." The mandate of the Ryerson University Library Council extends further and includes an annual review of the budget and "any budget amendments throughout the year, as necessary." The Dalhousie Library Council goes further still and not only considers but votes on library budget proposals, in addition to its role in policy formation and the development of Dalhousie Libraries. The broad mandate of the Dalhousie Library Council provides an example of collegial decision-making on a wide range of matters that affect the missions of academic libraries, and allows for increased transparency. Further research is necessary to determine if strong language results in stronger councils or, conversely, if stronger councils operate despite poor language in their terms of reference.

However, despite encouraging language, the findings indicate that overwhelmingly the councils function as information-sharing and discussion forums rather than decisionmaking bodies with any discernible authority. It appears that the development of collegial governance structures continues to struggle against the historically rooted and concentrated power of the university librarian (Savage, 1982). This can be assumed because voting and the making of motions were described in detail in only three of the documents analyzed (Dalhousie, Kwantlen, and Memorial). A library council with well-defined rules of procedure is one sign of its maturity as a governance body. Interestingly, Lang (2016) examined the governance of five small, public, not-for-profit tertiary institutions and noted that very casual and informal procedure can make for "highly participative" meetings (p. 54). However, Lang (2016) also observed that very informal deliberative processes "did not convey finality, and issues that had been putatively resolved at one meeting were reopened at later meetings, as if the previous meeting had never taken place" (p. 54). There are many ways to encourage council member participation, including orientation into members' rights, responsibilities, and rules of process; mentorship relationships between senior and junior members; online (anonymous) voting mechanisms which may be less intimidating; consent agendas to allow more time for discussion; and the distribution of materials at least one week ahead of the meeting so members have time to review and digest the information. When decision-making processes are unclear, the power balance is easily tipped, agendas can be hijacked by dominant voices, and issues can become stalled.

\section{Conclusion}

Governance is about the structure and process of how decisions are made and about how stakeholders make their voices heard (Bradshaw \& Fredette, 2009; Institute on Governance, n.d.; Sporn, 2006). Of the 96 Universities Canada member institutions, the authors estimate that approximately one third have a library council or like body. This study focused on the terms of reference of 23 library councils and examined their scope and purpose, rules of procedure, and connection to institutional governance structures. Anecdotal evidence, including conversations with colleagues and unpublished reports (Jacobs, 2008; Ryan, 2015), suggests there are more library councils either presently in operation, in the process of forming, or in the process of dissolution, so the present study should be read in the context of these limitations. Despite evidence of good governance practices by some councils, library council processes and structures within Canadian university libraries remain underdeveloped. The scope and role of the majority of the councils is that of a 
communication forum that serves in an advisory capacity to the university librarian. As has been demonstrated elsewhere (Revitt \& Luyk, 2016), such a role is not in the spirit of the original intention of library councils as outlined by the jointly released CACUL/CAUT Guidelines on Academic Status for University Librarians: Library governance was a crucial aspect of academic status for librarians. Nor does the current role of library councils align with the CAUT's assertion that library councils are not "mere information sharing bodies" (CAUT, 2014c), or with the Canadian Association of Professional Academic Librarians' (2015) Statement on Collegial Governance. Although the present analysis is based on an understanding that documents are "social facts" (Coffey \& Atkinson, 1997), further research is needed to determine the councils' effectiveness, scope, and impact on library policy, strategic direction, and service development. An analysis of library councils within the context of critical theory and its attention to power structures may prove particularly insightful.

\section{Acknowledgements}

The authors wish to thank the university librarians who responded to our email and generously shared the information and/or documents pertaining to library governance at their institutions. Without their participation, this study would have not been possible. The authors also want to thank the anonymous reviewers for their thoughtful and helpful comments.

\section{Endnotes}

1 Academic library annual reports or websites often include facts and figures that include visits to the library. In 2016/2017 academic year, the University of Guelph Library reported over 1.5 million visits, University of Victoria Libraries reported over 1.3 million visits, and Concordia University Library reported over 2 million visitors annually.

2 The International Federation of Library Associations'(IFLA) "Statement on Libraries and Intellectual Freedom," https://www.ifla.org/publications/ifla-statement-onlibraries-and-intellectual-freedom, and the Canadian Federation of Library Associations' "Statement on Intellectual Freedom and Libraries," http://cfla-fcab.ca/en/ guidelines-and-position-papers/statement-on-intellectual-freedom-and-libraries/, articulate the profession's fundamental principles and values.

3 CAUTLIB is an electronic mail distribution list (Listserv) of the CAUT that facilitates the discussion of topics of interest to Canadian librarians and archivists. CACUL-L was an electronic mail distribution list (Listserv) of the Canadian Association of College and University Libraries. The CACUL-L listserv and the Association are no longer active.

\section{References}

Ackerman, P. (1980). Governance and academic libraries. Library Research: An International Journal 2(1), 3-28.

Atkinson, P. A., \& Coffey, A. (1997). Analysing document realities. In D. Silverman (Ed.), Qualitative research: Theory, method, and practice (pp. 45-62). Thousand Oaks, CA: Sage. 
Beckman, M. (1976, March). Library governance. CAUT Bulletin, 24(5), 22. Retrieved from https://archive.org/details/cautbulletin24_5

Bohnsack, R. (2014). Documentary method. In U. Flick (Ed.), The SAGE handbook of qualitative data analysis (pp. 217-233). Thousand Oaks, CA: Sage. https://doi. org/10.4135/9781446282243

Bowen, G. A. (2009). Document analysis as a qualitative research method. Qualitative Research Journal, 9(2), 27-40. https://doi.org/10.3316/QRJ0902027

Bradshaw, P., \& Fredette, C. (2009). Academic governance of universities: Reflections of a senate chair on moving from theory to practice and back. Journal of Management Inquiry, 18(2), 123-133. https://doi.org/10.1177/1056492608326320

Brown, N. A. (1985). Managing the coexistence of hierarchical and collegial governance structures. College and Research Libraries, 46(6), 478-482.

Canadian Association of College and University Librarians/Canadian Assocation of University Teachers. (1979). Guidelines on academic status for university librarians. Ottawa, ON: Canadian Library Association.

Canadian Association of Professional Academic Librarians. (2015, April). CAPAL Statement on collegial governance. Retrieved from http://capalibrarians.org/wp/wpcontent/uploads/2016/o3/StatementOnCollegialGovernance2015AGM.pdf

Canadian Associaiton of Research Libraries. (2017, October 24). CARL Statistics/ Statistiques de l'ABRC 2015-2016 : Salaries/Salaires 2016-2017. Retrieved from http:// www.carl-abrc.ca/wp-content/uploads/2017/10/CARL-ABRC_Stats_Pub_2015-16-v2. pdf

Canadian Association of University Teachers. (1976, March). Guidelines on academic status for university librarians. CAUT Bulletin, 24(5), 19-22. Retrieved from https:// archive.org/details/cautbulletin24_5

Canadian Association of University Teachers. (2005). Collegiality: CAUT policy statement. Retrieved from https://www.caut.ca/about-us/caut-policy/lists/caut-policystatements/policy-statement-on-collegiality

Canadian Association of University Teachers. CAUT. (2018, December). Salaries, salary scales \& academic status report: Librarian salary \& academic status survey, 20142015 / 2015- 2016 / 2016-2017, Part I \& Part II. Ottawa, ON: Author.

Chan, Y. L., \& Richardson, A.W. (2012). Board governance in Canadian universities. Accounting Perspectives, 11(1), 31-55. https://doi.org/10.1111/j.1911-3838.2012.00030.x

Danton, J. P. (1934). Our libraries: The trend toward democracy. The Library Quarterly, 4(1), 16-27.

Davies, R. (2013). The changing higher education context. In M. Weaver \& M. Melling (Eds.), Collaboration in libraries and learning environments (pp.1-16). London, England: Facet.

Davis, B. (2015). Governance and administration of postsecondary institutions in Canada. In T. Shanahan, M. Nilson, \& L. Broshko (Eds.), Handbook of Canadian higher education law (pp. 57-78). Montreal, QC: McGill-Queen's University Press. 
Dekker, J., \& Kandiuk, M. (Eds.). (2014). In solidarity: Academic librarian labour activism and union participation in Canada. Sacramento, CA: Library Juice Press.

Eadie, T. (1978, February). Librarians and collective bargaining. CAUT Bulletin, 25(7), 13-14. Retrieved from https://archive.org/details/cautbulletin

Edwards, H. T. (2003). The effects of collegiality on judicial decision making. University of Pennsylvania Law Review, 151(5), 1639-1690. doi:10.2307/3313001

Ellis, R. H. (1980, September). Putting policy in the stacks. CAUT Bulletin, 27(5), 9-10. Retrieved from https://archive.org/stream/cautbulletin27_5\#page/9/mode/1up

Freedman, S. (2012). Collegiality matters: Massachusetts public higher education librarians' perspective. The Journal of Academic Librarianship, 38(2), 108-114. https:// doi.org/10.1016/j.acalib.2012.02.003

Fons, T. (2016, July). The tradition of library catalogues. Library Technology Reports, 52(5), 15-19. Retrieved from https://journals.ala.org/index.php/ltr/article/view/6032

Giroux, H. A. (2001). Public spaces, private lives: Beyond the culture of cynicism. Lanham, MD: Rowman \& Littlefied.

Giustini, D. (2007, November 8). Academic freedom, tenure \& collegiality for librarians [Blog post]. Retrieved September, 2018 from https://blogs.ubc.ca/dean/2007/11/ academic-freedom-tenure-collegiality-for-librarians/

Granfield, D., Kandiuk, M., \& Sonne de Torrens, H. (2011). Academic librarianship: A crisis or an opportunity? Partnership: The Canadian Journal of Library and Information Practice and Research, 6(2), 1-6. Retrieved from https://journal.lib.uoguelph.ca/index. $\mathrm{php} / \mathrm{perj} /$ issue/view/112

Institute on Governance. (n.d.). Defining governance. Retrieved from http://iog.ca/ defining-governance/

Jacobs, L. (2008). Library councils in Canadian academic libraries: A summary of responses [Unpublished report]. Retrieved from https://www.uleth.ca/dspace/ handle/10133/564

Jantz, R. C. (2017). Creating the innovative library culture: Escaping the iron cage through management innovation. New Review of Academic Librarianship, 23(4), 323328. https://doi.org/10.1080/13614533.2017.1388055

Jones, G. A., Shanahan, T., \& Goyan, P. (2004). The academic senate and university governance in Canada. The Canadian Journal of Higher Education, 34(2), 35-68. Retrieved from http://journals.sfu.ca/cjhe/index.php/cjhe/index

Lang, D. W. (2016). Five case stues of governance in tertiary education. Canadian Journal of Higher Education, 46(3), 42-38. Retrieved from http://journals.sfu.ca/cjhe/ index.php/cjhe/index

Lariviere, V., Haustein, S., \& Mongeon, P. (2016). Big publishers, bigger profits: How the scholarly community lost the control of its journals, Media Tropes, 5(2), 102-110. Retrieved from https://mediatropes.com/index.php/Mediatropes/article/view/26422 
Lesniaski, D., MacPherson, K. H., Fister, B., \& McKinzie, S. (2001, March 15-18). Collegial leadership in academic libraries. Paper presented at the ACRL Tenth National Conference, Denver, CO. Retrieved from http://www.ala.org/acrl/sites/ala.org.acrl/ files/content/conferences/pdf/lesniaski.pdf

Lipinski, T .A. (1999). The commodification of information and the extension of proprietary rights into the public domain: Recent legal (case and other) developments in the United States. Journal of Business Ethics, 22(1), 63-80.

Lougheed, P., \& Pidgeon, M. (2016). Exploring effective academic governance at a Canadian university. Canadian Journal of Higher Education, 46(3), 90-104. Retrieved from http://journals.sfu.ca/cjhe/index.php/cjhe/index

Lowry, C. B. (1974). The ACRL Standards and library governance, a comparison of the personnel systems of five major academic libraries (Master's thesis). Retrieved from ERIC database. (ED 108571)

Matthews, J. R. (2015). Library assessment in higher education. Santa Barbara, CA: Libraries Unlimited.

Merikangas, R. J. (1999). Historical and heuristic frameworks for shared governance in academic libraries: A documentary history, interpretation, and questions for library council and others of the University of Maryland. College Park, MD: The University of Maryland Libraries. Retrieved from ERIC database. (ED 441516)

Nelson, W. N., \& Fernekes, R. W. (2002). Standards and assessment of academic libraries: A workbook. Chicago, IL: Association of College and Research Libraries.

Nicholson, K. P. (2015). The McDonaldization of academic libraries and the values of transformational change. College \& Research Libraries, 76(3), 328-338. https://doi. org/10.5860/crl.76.3.328

Oakleaf, M. (2010). The value of academic libraries: A comprehensive research review and report. Retrieved from the Association of College and Research Libraries website: http://www.ala.org/acrl/sites/ala.org.acrl/files/content/issues/value/val_report.pdf

Pennock, L., Jones, G. A., Leclerc, J. M., \& Li, S. X. (2016). Challenges and opportunities for collegial governance at Canadian universities: Reflections on a survey of academic senates. Canadian Journal of Higher Education, 46(3), 73-89. Retrieved from http:// journals.sfu.ca/cjhe/index.php/cjhe/index

Petter, C. (2012, March 9-10). Librarians, governance, and the "Petch Procedures" at the University of Victoria. Paper presented at the Confederation of University Faculty Associations of British Columbia Conference, Vancouver, BC. Retrieved from http:// www.cufa.bc.ca/wp-content/uploads/2015/10/Academic-Governance-3.o.pdf

Ranganathan, S. R. (1931). The Five Laws of Library Science. London, England: Edward Goldston.

Revitt, E., \& Luyk, S. (2016). Library councils and governance in Canadian university libraries: A critical review. Canadian Journal of Academic Librarianship, 1(1), 60-79. Retrieved from https://cjal.ca/index.php/capal/issue/view/1726/showToc 
Ribaric, T. (2014). Collegial self-governance for professional librarians: The establishment and evolution of a library council at Brock University. In J. Dekker \& M. Kandiuk (Eds.), In solidarity: Academic librarian labour activism and union participation in Canada (pp. 277-289). Sacramento, CA: Library Juice Press.

Ryan, P. (2015). "This is Our Time": Towards a library council at York University Libraries [Unpublished report]. Retrieved from https://yorkspace.library.yorku.ca/ xmlui/handle/10315/30546

Savage, D. C. (1982). A historical overview of academic status for librarians. Canadian Library Journal, 39(5), 287-291.

Scott, J. W. (2002). The critical state of shared governance. Academe, 88(4), 41-48. https://doi.org/10.2307/40252188

Shaker, E., \& Shaban, R. (2017, November 14). Long overdue: Taking a closer look at university library funding [Blog post]. Canadian Centre for Policy Alternatives. Retrieved from http://behindthenumbers.ca/2017/11/14/longoverdue/

Sonne de Torrens, H. M. (2014). Academic librarianship: The quest for rights and recognition at the University of Toronto. In J. Dekker \& M. Kandiuk (Eds.), In solidarity: Academic librarian labour activism and union participation in Canada (pp. 277-289). Sacramento, CA: Library Juice Press.

Sporn, B. (2006). Governance and administration: organizational and structural trends. In J. J. F. Forest \& P. G. Altbach (Eds.), International handbook of higher education (pp. 141-157). Dordrecht, Netherlands: Springer.

Trosow. S. E. (2014). The commodification of information and the public good: New challenges for a progressive librarian. Progressive Librarian, 43, 17-29. Retrieved from http://www.progressivelibrariansguild.org/PL_Jnl/jnl_contents.shtml

Trotter, L. D. (2009). Building boards: A qualitative analysis of the perceptions of the role of external governors on university governing boards (Doctoral dissertation, Simon Fraser University). Retrieved from http://summit.sfu.ca/item/9844

Turk, J. L. (2010, August 25). Academic freedom for librarians: What is it, and why does it matter? [White paper]. Ottawa, ON: Canadian Association of University Teachers. Retrieved from https://www.mcgill.ca/maut/files/maut/2010.08.25_mcgill_ librarians.pdf

Weaver, M. (2013). Managing complex change collaboratively. In M. Weaver \& M. Melling (Eds.), Collaboration in libraries and learning environments (pp. 69-86). London, England: Facet.

\section{Contact Information}

Eva Revitt

John L. Haar Library

MacEwan University

revitte@macewan.ca 
Eva Revitt is a librarian at John L. Haar Library, MacEwan University. She is also a PhD candidate at the University of Alberta, Faculty of Education, Education Policy Studies. Her research interests include academic governance, educational leadership, academic freedom, labour issues in academia, and the role of the academic librarian.

Sean Luyk is a digital projects librarian at Cameron Library, University of Alberta. His research interests span the areas of collegial governance in academic libraries, local music collecting, music information retrieval, scholarly knowledge-making practices involving sound, and web archiving. 